\title{
Buffer Zone Concept and its Potential Implementation in Tasek Bera
}

\author{
Che Bon Ahmad ${ }^{1,2}$, Jamalunlaili Abdullah ${ }^{1}$, Jasmee Jaafar $^{2}$ \\ ${ }^{1}$ Centre for Environmental Design \& Management \\ ${ }^{2}$ Centre of Geospatial Technology Faculty of Architecture, Planning and Surveying, \\ Universiti7eknologi MARA, 40450 Shah Alam, Selangor, Malaysia \\ chebon848@salam.uitm.edu.my; cb2_nismo@yahoo.co.uk
}

\begin{abstract}
Tasek Bera (TB), one of the Protected Areas (PA) in Malaysia is an important site for natural ecosystem and community's life. Previous studies suggested that the activities around the Pas gave a great impact to the latter. Thus, the implementation and management of the surrounding areas - Buffer Zones (BZ) are necessary to safeguard the PAs. This study interviewed in- depth, six stakeholders of TB and the adjacent areas. Results indicated that although all stakeholders agreed on the overall concept and the importance of the BZs, there are disagreement in term of threats and opportunities derived from the potential implementation of it.
\end{abstract}

Keywords: Tasek Bera; Buffer Zones; Protected Areas; stakeholders.

eISSN 2514-751X @ C 2018. The Authors. Published for AMER ABRA cE-Bs by e-International Publishing House, Ltd., UK. This is an open access article under the CC BY-NC-ND license (http://creativecommons.org/licenses/bync-nd/4.0/). Peer-review under responsibility of AMER (Association of Malaysian Environment-Behaviour Researchers), ABRA (Association of Behavioural Researchers on Asians) and CE-Bs (Centre for EnvironmentBehaviour Studies), Faculty of Architecture, Planning \& Surveying, Universiti Teknologi MARA, Malaysia.

DOI: https://doi.org/10.21834/aje-bs.v3i7.255 


\subsection{Introduction}

Protected Areas in Malaysia exist in the form of wildlife reserves, national parks, state parks and wetlands areas. These are among the most dynamic environments, a means to uphold the cyclical relations within the ecosystem and thus maintain the ecological services such as clean water and air, biodiversity hotspot and supporting life of the people in the areas and also a melting pot for nature tourism for the country (Nyaupane \& Poudel, 2011). On the other hand, it provides some conflicting call between biodiversity conservation and socio-economic interests among stakeholders ((Rastogi, Badola, Hussain, \& Hickey, 2010) ; (Liu, Ouyang, \& Miao, 2010).

Buffer Zone has gone through a massive evolvement starting approximately back in 1950s until recently it becomes a vital solution to protect the Protected Areas through various international and national legal means. One of the latest definitions is by (Gilmour \& Nguyen, 1999), who defined it as a "clearly demarcated areas, with or without forest cover, lying outside the boundaries of Protected Areas that are managed to enhance the conservation of the Protected Areas and of the Buffer Zone itself, while providing benefits for people living around the area".

Table 1: Evolution of the Concept of Buffer Zones for Protected Areas

\begin{tabular}{|l|l|}
\hline Before 1950s & Protect the people and crops from animals leaving the Protected Areas \\
\hline 1950 s & $\begin{array}{l}\text { Protect the conservation area from negative human influences from the } \\
\text { surrounding area }\end{array}$ \\
\hline 1960 s & $\begin{array}{l}\text { Conservation and development (transition point between conserved } \\
\text { regions and human population) }\end{array}$ \\
\hline 1970 s - 1990s & $\begin{array}{l}\text { Integrated Conservation \& Development Projects (ICDP) } \\
\text { alleviate human impacts on conservation region }\end{array}$ \\
\hline $2000 \mathrm{~s}$ & $\begin{array}{l}\text { Substitute to nature/forest loss resulted from increasing global awareness } \\
\text { of biological and ecosystem value }\end{array}$ \\
\hline $2010 \mathrm{~s}$ & $\begin{array}{l}\text { "Extension buffering" } \\
\text { - Ecological buffering (extension of core habitat areas) } \\
\text { - Socio buffering (provide goods and services to human) }\end{array}$ \\
\hline
\end{tabular}

Studies (Che Bon, Jasmee, \& Jamalunlaili, 2012; Stræde \& Treue, 2006)have proven that activities around the Protected Areas such as rubber and oil palm plantations, aquaculture farms and over harvesting of natural forest products could increase the pressure and provide significant impacts to the Protected Areas. Thus, the effective management of the Buffer Zones have long been one of the most important mechanisms. The areas serve as environmental buffering, to filter out inappropriate influences such as solid waste disposal, fertilizer and pesticide run-off from surrounding activities (DeFries, Karanth, \& Pareeth, 2010). Equally true, stakeholders of the area play a pivotal role in making sure the implementation of buffer zones successfully by accommodating biodiversity conservation objectives in concerts with equality and democracy - 'win-win situation'. 
Although the concept of the Buffer Zones have been mentioned in several management plans, but implementing it in Malaysia require more efforts (Mohd Salleh, Jamalunlaili, Anuar, $\&$ Che Bon, 2010)Not many Protected Areas in Malaysia takes into account the perspectives and involvement of its stakeholders. This is regretful since conflicts among human and natural resources are rather extensive. This paper presents the results of the stakeholders' perspective for Tasek Bera, one of the important Protected Area in Malaysia. The study aims to determine the stakeholders' knowledge and perception on the concept of Buffer Zone and identify the threats and opportunities ofits potential implementation which include their interests, knowledge, understanding, awareness and participation towards the conservation purposes and socio-economic wellbeing. The data is based on in-depth interviews using semi structured questionnaires on six selected stakeholders of the Protected Areas and immediately around it. Selection of the stakeholders was based on their expertise, knowledge and involvement in the Buffer Zone planning and their position in the management authorities. Though it is still a preliminary stage, it will somehow lead to the next step of the study in the near future.

\section{Study Area}

Tasek Bera area is the largest natural fresh-water wetland ( 31,255 hectares), the first Ramsar Site in Malaysia, and one of the world's outstanding PAs. Since its establishment, its resources have been subject to conflict among human and conservation. Located in the central lowlands of Peninsular Malaysia, this area has a significant impact not only because of rich biodiversity but also from recreational, educational and economic(Crawford, 1999).TB is a home to Semalai community who has lived off the wetland for about 600 years(Wetlands, 1999). BZs have been included in Bera DistrictStructure Plan under the zone for environmental protection specifically for water catchment's area. Although TB has been listed under Ramsar convention, it is relevant to various agreement including World Convention on Biological Diversity, Malaysian Policy on Biological Diversity and Convention of Nature and Natural Resources and Convention on International Trade in Endangered Species (CITES).
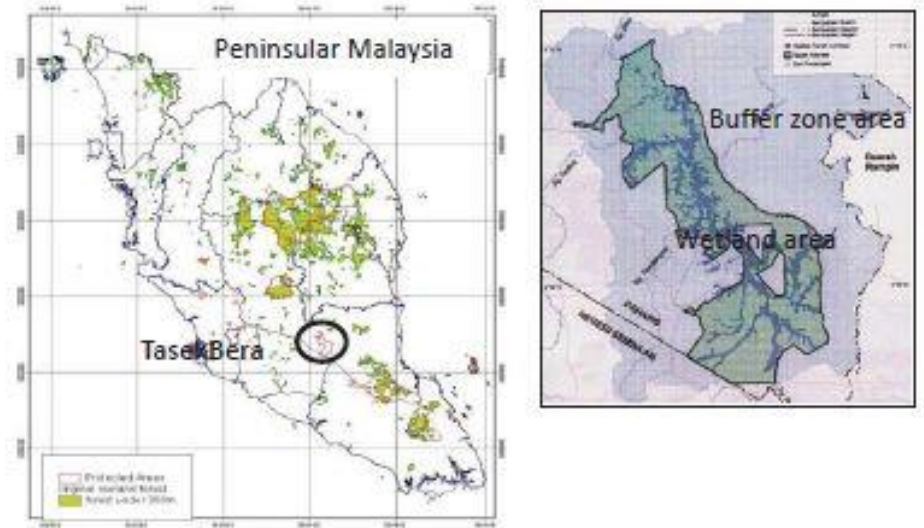

Figure 1: Map of Tasek Bera Ramsar Site, Malaysia showing Boundary of Wetland and BZs 
Under its Integrated Management Plan (IMP) (1996-1999) Tasek Bera has been divided into three merged zones which include specialized management zone, suitable utilization zone and buffer zone. The entire Buffer Zones (77,380 hectares) covering the most part of the catchment area, mainly consist of government owned plantation schemes of oil palm and rubber, Cini Forest Reserve, Bukit lbam Proposed Forest Reserve and settlements of Semalai community. Using guidelines from Ramsar convention, IMP was implemented by Pahang State Government with technical inputby Wetlands International-AsiaPacific, funded by DANCED (Danish Corporation for The Environment and Development) and managed by Department of Wildlife and National Park.

\subsection{Methodology}

Identifying the stakeholder's was based on their expertise, knowledge, experiences and positions in the organization. The representatives of an organization are likely to be the director or the person in-charged who is suitable to be interviewed. Six main stakeholders were identified - Department of Wildlife and National Park (DWNP) who is responsible for the management of TB, Bera District Office (BDO), Department of Orang Asli Affair (JHEOA), Semalai community head, Federal Land Development Authority (FELDA) and WWFMalaysia. Although there were more stakeholders of Tasek Bera, for example, tourism sector, tourist, researchers, irrigation department and local media, only six were selected for this study preliminary research and all six stakeholders are directly related to Tasek Bera in terms of management, enforcement and legislation, indigenous people, plantation management and conservation. Data was then collected through an in-depth interview with representatives from each stakeholder. This study was not intended to evaluate the conservation objectives but rather to lay out the stakeholders' perception to help improve the management with guideline formulation and implementation.

\subsection{Results and Discussions}

The six key stakeholders and their position are listed in Table 2 . Some belong to more than one organization reflecting the complexity of stakeholder relations.

Table 2: Profile of Stakeholders of Tasek Bera

\begin{tabular}{ll}
\hline Stakeholder & Description and key characteristics \\
\hline DWNP & $\begin{array}{l}\text { Director. Oversee the management, of TB. Has } 14 \text { years of } \\
\text { experiences in DWNP with various positions. Expert in Protected } \\
\text { Areas, conservation project and Buffer Zones. }\end{array}$ \\
Bera District Office & $\begin{array}{l}\text { Assistant District Officer. More than five years working experience in } \\
\text { local authority. }\end{array}$ \\
JHEOA & Senior Officer. Thirty five years of experience in JHEOA. \\
Semalai community & Head of Semalai community. \\
FELDA & Head of Plantation Units. More than 15 years working experience in \\
WWF-Malaysia & SELDA.
\end{tabular}


For the purpose of this paper, the findings are elaborated according to four sections derived from the interviews.

\section{Stakeholders Understanding on the Overall Concept and Significant Importance of Buffer Zone for Protected Areas}

All stakeholders in general, agreed that the definition of Buffer Zones is "any area peripheral to a Protected Areas, inside or outside, in which activities are implemented or the area managed with the aim of enhancing the positive and reducing the negative impacts of conservation on neighboring communities and neighboring communities on conservation"(Wild, Cunningham, \& Mutebi, 1996). This has shown that all stakeholders understood the significant importance of Buffer Zones and at the same time agreed for Buffer Zones to be inside or outside of the Protected Areas. Placement of the Buffer Zones inside the Protected Areas contradict the core concept, policy and management objectives whereby establishing Buffer Zones outside and around the PAs is largely accepted internationally. The findings of the study further exposed the understanding of the stakeholders on the overall significant implementation of buffer zones. All stakeholders agreed the implementation contributed to the preservation and improvement of natural habitat whilst two stakeholders (DWNP and WWFMalaysia) agreed the implementation is to improve water quality and reduce the impacts of pollution due to run-off of chemical fertilizer into the lake. Two stakeholders (JHEOA and WWF-Malaysia) also agreed that Buffer Zones are to enhance environmental services provided by protected areas, for example, watershed protection.

With regards to social significance, three stakeholders (DWNP, BDO and WWF-Malaysia) agreed that BZs are to provide a flexible mechanism for resolving conflicts between the interest of conservation and those of inhabitants of adjacent lands. These stakeholders (JHEOA, FELDA and WWF-Malaysia) agreed that BZs help to build local and regional supports for conservation programs.

Among the six stakeholders, only two (DWNP and JHEOA) disagreed that Buffer Zones contributed to the economic benefit through income from tourists and local products and fee from researchers. JHEOA was the only stakeholder who agreed that Buffer Zones provide benefit through opening land for farming activities for Semalai community. Two out of six stakeholders (BDO and JHEOA) agreed that the implementation of Buffer Zones gave benefit to each party involved. It shows conflict of interests among stakeholders and are likely not willing to participate in the implementation of Buffer Zones. It can also be concluded that the concept of integrated stakeholders partnerships introduced by Tasek Bera Management Plan was not clearly understood.

\section{Stakeholders Understanding on the Threat of Buffer Zone's Potential Implementation} In order for Buffer Zone management to succeed, it very much depends on the participation and support of the stakeholders. Ensuring public participation, co-management and capacity building, awareness raising and training are all issues to be addressed when implementing it. Another crucial issue is all stakeholders should be aware of the problems faced by protected areas itself. In this study, it was found that all stakeholders suggested that the main issue was water pollution caused by plantation activities around the area. In addition, all stakeholders 
suggested that other key issues were illegal fishing and hunting of wildlife and extraction of non-timber product from Protected Areas. Three of them (DWNP, JHOEA and WWF-Malaysia) further suggested the issues such as open burning, uncontrolled agricultural activities and demand of oil palm and rubber superseded the conservation purposes.

Surprisingly, in general most of the stakeholders were unaware of the ecological, socialeconomic and institutional threats. Environmental conditions including vegetation and landscape of Buffer Zones, should preferably be similar to the Protected Areas and the ecosystem of the Buffer Zones should be the extension of the Protected Areas to provide corridor function for migration animals. As a result, the objectives of nature conservation often conflict with development objectives. In contrast, four stakeholders (DWNP, JHEOA, Semalai community and WWF-Malaysia), agreed that fertilizer and pesticides run-off was the main contribution factor to the pollution of Tasek Bera. Their opinioned that fertilizer and pesticides may increase the level of water and harmful to wildlife species, and therefore required to control the planting activities and land opening surrounding Tasek Bera. FELDA contrasted the use of fertilizer is essential to increase the yield of palm oil.

Whilst, social and economic threats include wrongly balanced trade- offs took place between the Buffer Zone's impacts and sustainability and insufficient ownership of the Buffer Zone initiative by local communities. The social structure and culture of people involved in the potential implementation of the Buffer Zones, particularly stakeholders and beneficiaries, must be fully integrated in the management approach. The other institutional causes were lack of legal authority to manage the Buffer Zones, technical plan for Buffer Zone development were too detailed; Buffer Zone initiatives often bypassed the authorities responsible for rural development and unclear land status.

The findings further unlock the issues with regards to the Buffer Zone's policy whereby all of the stakeholders have come up with different opinions. According to DWNP, although they took action on the BZ's policy and has managed the Tasek Bera, their authority did not include an oil palm plantation owned by FELDA. FELDA, on the other hand, while applied the Buffer Zone's policy imposed on them has stated it was a tough regulation, for example, in controlling the fertilizer run-off, it is beyond their power if the fertilizer flow into Tasek Bera during the rainy season. All stakeholders agreed except DWNP that the policy, prepared by DWNP provide more advantages to DWNP but not to other parties. So it is difficult for the policy to be implemented.

Enthusiastically, all stakeholders are fully aware of the effects in the future if the Buffer Zone could notbe implemented. Most of them suggested that the pollution will become worst in the future if the natural habitat of the Buffer Zone is not protected. The biodiversity of flora and fauna in the lake will be gone in future. The healthy ecosystem of Tasek Bera will be deteriorated leading to negative social impacts to Semalai community, local authority, tourist sector and other related organizations and bodies and biodiversity loss.

\section{Stakeholders Understanding on the Opportunity of the BZ's Potential Implementation} Most of the stakeholders agreed that substantial potential of Buffer Zones accrue to Semalai community through nature tourism activity, public awareness program, education and recreation. All stakeholders agreed on the potential function of Buffer Zones, as the 
extension of existing Protected Areas, provide feeding and breeding habitat and shelter for flora and fauna. From the socio-economic perspectives, all stakeholders, except BDO agreed that agro-forestry can be highly appreciated in Buffer Zones and various economic opportunities such as tourism activity will appear. Most of them also agreed on the importance of giving training, knowledge, flexible personnel management and incentive structure, beneficial in enforcement and legislative instruments and vital for the local community to be given the secure rights to use and control access to natural resources as an establishment in long-term sustainability. Collaboration among all stakeholders, agreed by all, is the main factor in order for Buffer Zones to be successfully implemented. There should be a management committee for the Buffer Zone with representative from the management authority of Tasek Bera Ramsar Site, other relevant government agencies, district office, local communities including indigenous people, private companies operating in the surrounding area and NGOs. The responsibility for managing the BufferZones should be shared byall concerned parties and decisions should be made in a consultative manner and following the principles of 'Free and Prior Informed Concerned' (FPIC), equitable access and sharing of benefits and the precautionary principle.

\subsection{Conclusion}

\section{Tasek Bera as a Protected Area}

From the findings, all the stakeholders are fully aware that Tasek Bera is a Protected Area and beneficial for the future function of it as the largest fresh water and home for many flora and fauna. The main focus of Tasek Bera is to upgrade the unique values through conservation of ecosystem and biodiversity of species and genetic.

\section{Semalai Community}

Buffer Zones are particularly valuable to Semalai community. They depend on it for economic resources in fields of agricultural and tourism and collection natural resource product. Thus, it requires clear demarcated boundary, to avoid illegal hunting, harvesting of natural resource products. Pollution can be minimized by the power of enforcement and authority. Being the community who has lived in the area for more than 600 years, their knowledgeand experience about the site should notbeunder estimated and they should be given a power to perform their daily activities and manage the site.

\section{Stakeholders Partnership}

The crucial issue highlighted is an authoritative power to manage the site. PERHILITAN hold the authoritative power to manage the PAs but not the BZs, although the implementation of the Integrated Management Plan is under their control. Thus, the best solution is through stakeholders' partnership. There should be a management committee for the BZ with the representation from the management authority of $\mathrm{TB}$, other relevant government agencies, district office, local communities including indigenous people, private company operating in the surrounding areas and NGOs. The responsibility for managing the BZs should be 
shared by all concerned parties and decisions should be made in consultative manner.

\section{Acknowledgements}

The authors would like to extend the utmost appreciation to the respondents for their exceptional dedication and enthusiasm and for sharing their valuable time and support. The authors also acknowledge the constructive comments for reviewing the manuscript.

\section{References}

Che Bon, A., Jasmee, J., \& Jamalunlaili, A. (2012). Buffer zone characteristicsforprotectedareas:apreliminary study of Krau Wildlife Reserve. In C. A. Brebbia \& S. S. Zubir (Eds.), Management of Natural Resources, Sustainable Development and Ecological Hazards (pp. 27- 36). Shah Alam: WIT Press.

Crawford, P. (1999). Management zonation at Tasek Bera Ramsar Site: Striking the balance. Paper presented at the Workshop on Zoning Systems for Protected Areas in Peninsular Malaysia: Towards Sustainable Management of Biological Resources, Kuala Lumpur.

DeFries, R., Karanth, K. K., \& Pareeth, S. (2010). Interactions between protected areas and their surroundings in human-dominated tropical landscapes. [doi: 10.1016/j.biocon.2010.02.010]. Biological Conservation, 143(12), 28702880 .

Gilmour, D. A., \& Nguyen, V. S. (1999). Buffer Zone Management In Vietnam: lucn - The World Conservation UnionVietnam Programme.

Liu, J., Ouyang, Z., \& Miao, H. (2010). Environmental attitudes of stakeholdersand theirperceptions regarding protected area-community conflicts: A case study in China. [doi: 10.1016/j.jenvman.2010.06.007]. Journal of Environmental Management, 91(11), 2254-2262.

Mohd Salleh, D., Jamalunlaili, A., Anuar, M. N., \& Che Bon, A. (2010, 2010). Criteria for Buffer Zone Delineation in Taman Negara Pahang. Paper presented at the UiTM-Perhilitan Taman Negara Projects, Shah Alam.

Nyaupane, G. P., \& Poudel, S. (2011). Linkages among biodiversity, livelihood, and tourism. [doi: 10.1016/j.annals.2011.03.006]. Annals of 7ourism Research, 38(4), 1344-1366.

Rastogi, A., Badola, R., Hussain, S. A., \& Hickey, G. M. (2010). Assessing the utility of stakeholder analysis to Protected Areas management: The case of Corbett National Park, India. [doi: 10.1016/j. biocon.2010.04.039]. Biological Conservation, 143(12), 2956-2964.

Stræde, S., \& Treue, T. (2006). Beyond buffer zone protection: A comparative study of park and buffer zone products' importance to villagers living inside Royal Chitwan National Park and to villagers livinginitsbufferzone. [doi: 10.1016/j.jenvman.2005.03.017].Journal of Environmental Management, 78(3), 251-267.

Wetlands, I., - Asia, Pacific. (1999). Integrated Management Plan - Tasek Bera Ramsar Site. Wetlands International - Asia Pacific.

Wild, R., Cunningham, A. B., \& Mutebi, J. (1996). People, parks and plant use: networks to enhance the conservation of montaneforestsin Uganda, East Africa. The role of networks, 112-121. 